\title{
Study of the flow around cofferdams constructed in running water through computational model
}

\section{Estudo do escoamento na ponta de aterro de ensecadeiras construídas em água corrente através de modelo computacional}

\author{
Cláudia Trevisol Dalmora ${ }^{1}$ and José Junji Ota ${ }^{2}$ \\ ${ }^{1}$ Intertechne Consultores S.A., Curitiba, PR, Brasil \\ ${ }^{2}$ Universidade Federal do Paraná, Curitiba, PR, Brasil \\ E-mails: claudiadalmora@hotmail.com (CTD), ota.dhs@ufpr.br (JJO)
}

\begin{abstract}
River closure to provide a dry area for the construction of the works in the river bed must be carefully performed because a failure can lead to serious and costly delays. By means of a computational approach, using the FLOW 3D ${ }^{\circledR}$ software, this paper studies the hydraulic behavior of the flow around a cofferdam constructed in running water. The computational model was validated using results of an experimental investigation. Then the effect of changing the cofferdam configuration on the flow characteristics in this region was analyzed. This study showed that the computational model adequately reproduces this type of flow and that changing the configuration of the cofferdam: increasing the width of the crest or decreasing the embankment slope affects the flow curvature and positively affects the river closure process.
\end{abstract}

Keywords: River closure; Cofferdam; End dumping; Computational modeling.

\section{RESUMO}

O fechamento de rio para proporcionar área seca no leito é uma etapa importante durante a construção de uma obra hidráulica e deve ser executada com cuidado. Uma falha nesta etapa pode levar a um atraso sério e custoso no cronograma. Este trabalho estuda o comportamento do escoamento no entorno da ponta de aterro de ensecadeira construída em água corrente por meio da modelação computacional no software FLOW $3 \mathrm{D}^{\circledR}$. A validação do modelo computacional foi realizada utilizando resultados de uma investigação experimental em modelo hidráulico reduzido. Em seguida, efetuou-se a análise do efeito da alteração da configuração da ponta de aterro nas características do escoamento nessa região. O estudo mostrou que o modelo computacional reproduz de forma adequada o tipo de escoamento em questão e que as alterações da geometria da ponta de aterro estudadas: aumento da largura da crista e diminuição da inclinação do talude da ensecadeira resultam na alteração da curvatura do escoamento na ponta de aterro e afetam positivamente o processo de fechamento do rio.

Palavras-chave: Fechamento do rio; Ensecadeira; Lançamento lateral progressivo; Ponta de aterro; Modelo computacional. 


\section{INTRODUCTION}

River management during the construction of hydraulic works is an important activity. A failure at this stage may lead to serious and expensive delays in the schedule. In this activity special attention must be given to the rock-fill cofferdams. Their main function is to provide a dry area for construction on the river bed (ICOLD, 1986).

Rockfill is widely used in temporary river diversion works, since it presents characteristics such as resistance to entrainment by water, allowing it to be deposited in running water, adaptability to natural river bed conditions and low cost because the material used is generally from excavations for the work itself.

A stock of rock-fill must be prepared to perform successful river closure. Initially the material may be fine, but as the closure advances, there is faster flow, and a greater difference in level in the gap, which makes it difficult to close, and requires a stock of larger materials to conclude the river closure. It is precisely at this stage that knowledge of the limit of stability of each material is important, because large-diameter materials may be scarce at the construction site.

There are two main methods of river closure with rockfill: the transverse or frontal dumping method and the end dumping method also known as the lateral progressive method, and the latter is the subject of this study (ISBASH; KHALDRE, 1970; ICOLD, 1986).

The rockfill stability conditions used in river closure involve a critical condition of entrainment of the material released into running water. Observation of several works in scale models, led to questioning whether the curvature of the streamlines in end dumping closure method can affect this critical condition. This study was performed by simulations in a three-dimensional computational model. The following main activities were performed for this purpose:

a) Validation of the FLOW $3 \mathrm{D}^{\circledR}$ computational model using physical model results for flow simulations in a channel that is partially obstructed by a cofferdam;

b) Study of how the curvature of the streamlines imposed by the cofferdam geometry may affect the fields of velocities and shear stresses in the end dumping region.

\section{LITERATURE REVIEW}

Cofferdams for river closure are usually designed utilizing formulations defined based on theoretical considerations, experimental observations in the laboratory and successful experiments on prototypes.

In river closure, using the method of transverse dumping, the stones are deposited as uniformly as possible along the entire cross-section of the river, changing the embankment to the desired height. For this it is necessary to use equipments such as cableways, fixed or floating bridges, cranes, barges, conveyor belts or dredges. In the river closure done according to the progressive lateral method, also called end dumping, rock-fill deposition can occur from one or both banks until the river section is completely closed and its final crest elevation is completed later. The crest of the embankment is wide enough to allow access to the machinery and its top, during the closure phase, is usually one meter above the upstream water level (ICOLD, 1986). Figure 1 illustrates the typical configuration of a river closure using the lateral progressive method.

Classical studies in the field by Isbash (1938), Bouvard (1960) and ICOLD (1986) are shown next. They are based on theoretical considerations, experimental observations in the field and laboratory, and use simplified hypotheses, aiming to generalize the results and place them within reach of the designers. Their purpose is to calculate the size of the material to close the river.

\section{Equations based on critical velocity}

The equations proposed by Isbash (1938) and by Bouvard (1960) are founded on critical velocity. Both used the transverse dumping method to construct cofferdams in their studies. However, the knowledge acquired is also valid to calculate the deposition using the end dumping method (CURI, 1986; PEREIRA, 2001).

According to Isbash (1938), the diameter ( $d$ ) of the rocks to ensure stable rockfill formation may be determined by equations:

$$
\mathrm{V}_{\mathrm{m}}=\mathrm{Y}_{\mathrm{d}}^{\prime} \sqrt{2 \mathrm{~g} \frac{\gamma_{\mathrm{S}}-\gamma}{\gamma}} \sqrt{\mathrm{d}}
$$

$V_{M}=Y_{d} \sqrt{2 g \frac{\gamma_{S}-\gamma}{\gamma}} \sqrt{d} \sqrt{f^{\prime} \cos \alpha \operatorname{sen} \alpha}$

in which $V_{\mathrm{m}}$ and $\mathrm{V}_{\mathrm{M}}$ represent the critical velocity for rocks without lateral support and with lateral support, respectively; $Y_{d}^{\prime}$ and $Y_{d}$ are non-dimensional coefficients, obtained experimentally, that represent rocks without lateral support and with lateral support, respectively; $g$ is acceleration of gravity; $\gamma_{\mathrm{s}}$ and $\gamma$ the specific weight of the material and the water, respectively; f' represents a non-dimensional numerical coefficient and $\alpha$ is the angle that creates the plane of the bottom surface with the horizontal.

Isbash (1938) cites two positions of the rock in relation to its support over the others in a cofferdam, as shown schematically in Figure 2. In the first position, Figure 2(a), the rock does not have lateral support. The critical velocity of entrainment $\left(\mathrm{V}_{\mathrm{m}}\right)$ for this condition is given by Equation 1 with $Y_{d}^{\prime}$ equal to 0.86 , obtained experimentally. This is the case in which the rock is most exposed. The second position, Figure 2(b), is when the rock is on the same plane as its neighbors, presenting greater stability to entrainment.

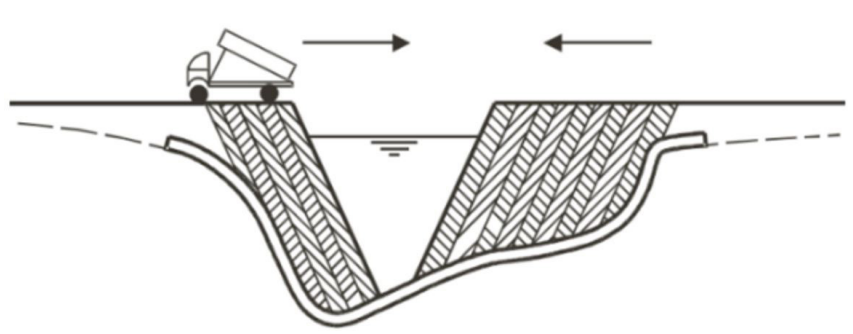

Figure 1. Typical configuration of the river closure using the lateral progressive method. Source: CIRIA et al. (2007). 


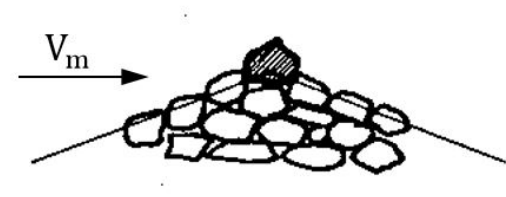

(a)

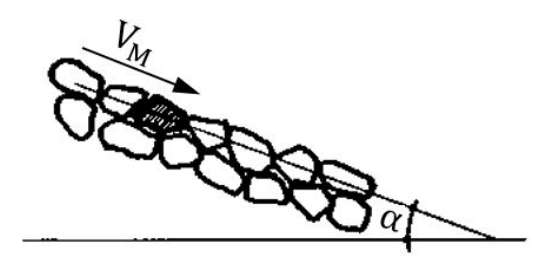

(b)

Figure 2. Different positions of the rocks in a rockfill cofferdam. Source: Pinto (1977).

The critical velocity of this position $\left(\mathrm{V}_{\mathrm{M}}\right)$ is given by Equation 2 with $\mathrm{Y}_{\mathrm{d}}$ equal to 1.2 obtained experimentally (PINTO, 1977).

For the specific situation of cofferdams, angle $\alpha$ (Equation 2) is generally very small, so that one can then consider $\sqrt{f^{\prime} \cos \alpha \operatorname{sen} \alpha}=1$. Using the values $Y_{d}^{\prime}=0.86$ and $Y_{d}=1.2$. Adopting the specific density $\left(\mathrm{S}_{\mathrm{S}}\right)$ of the material equal to 2.65 , corresponding to a reference value for quartz, since this is the mineral most commonly found in rivers, and that most of the natural materials have a specific density similar to this value, the relation $\left(\gamma_{\mathrm{s}}-\gamma\right) / \gamma$ results equal to 1.65. (CHANSON, 2004; CHAUDHRY, 2008). Thus, Equations 1 and 2 can be reduced to Equations 3 and 4, respectively:

$\mathrm{V}_{\mathrm{m}}=5 \sqrt{\mathrm{d}}$,

$\mathrm{V}_{\mathrm{M}}=7 \sqrt{\mathrm{d}}$,

Bouvard (1960) proposed a purely empirical equation (Equation 5), very similar to Equation 4, which relates the mean velocity of flow (v) to the diameter of the material (d):

$\mathrm{v}=6.71 \sqrt{\mathrm{d}}$,

Simplifying, the mean velocity of flow at the rockfill can be related to the difference in water level $\Delta \mathrm{h}$ generated by the cofferdam, according to the equation:

$\mathrm{v}=\sqrt{2 \mathrm{~g} \Delta \mathrm{h}}$,

Thus, substituting Equation 4 in Equation 6, there is: $\mathrm{d}=0.4 \Delta \mathrm{h}$,

Therefore, as shown by Equation 7, the greater the difference in water level created by the gap, the larger the diameter of the material needed for closure.

\section{Equations based on the critical shear stress}

Critical shear stress is a result of the forces of flow to move the particle in the direction of flux (GRAF, 1984). The Task Committee on Preparation of Sedimentation Manual (1966) suggests the use of critical shear stress instead of critical velocity to study the erosive action of water on the river bed. It also says that the advantage of using shear stress to specify the critical conditions is that it is a single parameter, while velocity must be associated with depth or with the position in which it was observed due to the distribution of flow velocities.

The vertical profile of velocities for a two-dimensional flow with a free surface over a flat bed of sediments is given by the equation (TASK COMMITTEE ON PREPARATION OF SEDIMENTATION MANUAL, 1966):

$\frac{\mathrm{u}}{\mathrm{u}_{*}}=\mathrm{a}_{\mathrm{r}}\left(\frac{\mathrm{u}_{*} \mathrm{k}_{\mathrm{s}}}{\mathrm{v}}\right)+5,75 \log \frac{\mathrm{y}}{\mathrm{k}_{\mathrm{s}}}$,

in which $\mathrm{u}$ is the velocity at a distance $\mathrm{y}$ above the bottom; $\mathbf{u}_{*}$ shear velocity given by equation: $\sqrt{\tau_{\mathrm{o}} / \rho}$, i.e., the shear velocity is a measure of the shear stress at the bed; $a_{\mathrm{r}}$ function of the particle Reynolds number $\left(R_{\mathrm{e}}^{*}\right)$, obtained experimentally $\left(\mathrm{R}_{\mathrm{e}}^{*}=\mathrm{u}_{*} \mathrm{~d} / \mathrm{v}\right) ; \mathrm{k}_{\mathrm{s}}$ characteristic dimension of the sediment; $v$ kinematic viscosity of the fluid; $\tau_{\mathrm{o}}$ shear stress at the bed; $\rho$ specific mass of fluid; and $\mathrm{y}$ depth in relation to the bed.

Equation 8 shows that if two flows at different depths have identical sediment beds and the same shear stress at the bottom, the velocities at any distance " $y$ " above the bottom will also be the same in the two flows. However, since the mean velocity occurs at a constant fraction of depth, the deeper flow will have a higher mean velocity. In this way it is clear that the mean velocity only cannot express the erosive action of water on the bed, and that to specify the totality of the conditions, the depth must be taken into account (TASK COMMITTEE ON PREPARATION OF SEDIMENTATION MANUAL, 1966).

The bed particles begin to move when the values of shear stress at the bed $\left(\tau_{\mathrm{o}}\right)$ reach values higher than a critical value of the shear stress at the bed $\left(\tau_{\mathrm{oc}}\right)$ (CHANSON, 2004).

The experimental results most accepted regarding critical shear stress are those of Shields (1936), whose parameter refers to the movement of particles with a "d" diameter over others of the same size. The Shields diagram is shown in Figure 3 in which it is possible to observe the tendency to maintain the relation $\frac{\mathrm{u}_{*}{ }^{2}}{\left(\mathrm{~S}_{\mathrm{s}}-1\right) \mathrm{gd}}$ equal to the value 0.056 with the increase of the particle Reynolds number.

Equaling expression $\frac{\tau_{0}}{\gamma\left(\mathrm{S}_{\mathrm{s}}-1\right) \mathrm{d}}$ to the constant value of 0.056 and setting $\mathrm{S}_{\mathrm{s}}=2.65$ and $\gamma=9810 \mathrm{~N} / \mathrm{m}^{3}$, we have:

$\tau_{\mathrm{oc}}=906 \mathrm{~d}$,

where $\tau_{\mathrm{oc}}\left(\mathrm{N} / \mathrm{m}^{2}\right)$ is the critical shear stress at the bed.

According to Figure 3, this relation is applied to $\mathrm{R}_{\mathrm{e}}^{*}>500$, the range at which the critical conditions occur at the prototype 
works, but not mandatorily in the scale model studies. Therefore, the simple rules expressed, for instance by Equations 3, 4, 5 or 7, do not appear to be sufficient.

\section{Hydraulic scale model studies}

The study of river closure in a scale model is usually done as follows: beginning with the alignment chosen by the project, the closure process is initiated in the scale model considering small diameter material. The material is deposited at a rate equivalent to that which will be adopted in the prototype. On reaching the limit of stability of the material, the main information is recorded at end dump, such as water velocity and levels upstream and downstream

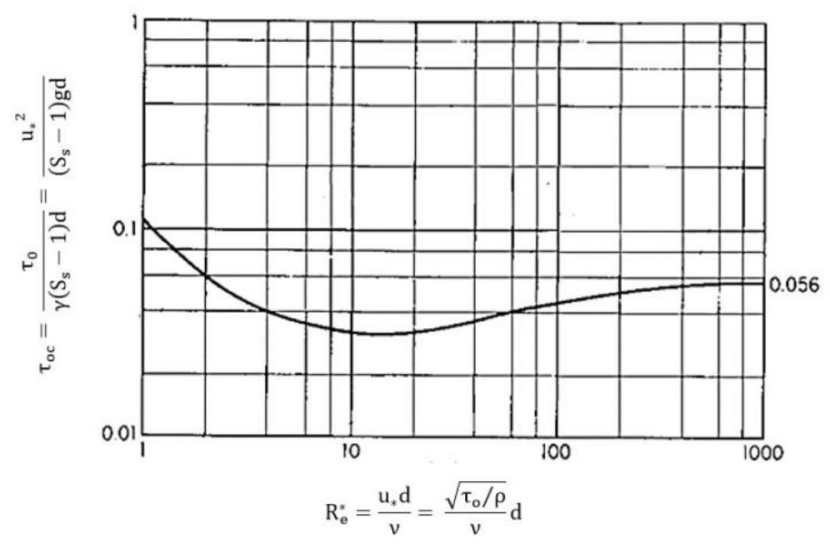

Figure 3. Shields diagram. Source: adapted from Henderson (1966). of the cofferdam. Then the process of river closure with larger material is continued until the limit of stability of this material is reached. Whenever the material reaches the limit of stability it is changed to continue the closure process without losses due to entrainment.

For instance, Figure 4 illustrates one of the experimental studies performed at the Centro de Hidráulica e Hidrologia Professor Parigot de Souza - CEHPAR, about the closure of the Paraná River to enable the construction of the Itaipu Hydroelectric Plant. In this example, the crest of the closing cofferdam is broad, and consequently the curvature of the end dump is quite gentle. However, there are cases in which the river is not deep, and cofferdams are built with a narrower crest, leading to a very marked curvature at the end dump.

The study of the river closure on a scale model, besides defining the material needed for closure, enables mapping the main difficulties and characteristics of that closure. When there is more than one work front, the study allows choosing the best sequence for depositing the material.

\section{Comparison of the results in scale models and in prototypes}

Returning to practical rules, Figure 5, by Neidert and Tozzi (1986), presents, for the methods of Isbash, Bouvard and Shields, the correlation between the diameter of a sphere equivalent of the material, the weight of the blocks and critical velocity. The same figure shows the stability conditions of an isolated cube, results of the Passamaquoddy (United States) prototype, the model of the Rance Dam (France), the model of the Bonneville Dam (United States), models of various works studied at CEHPAR Hydraulic

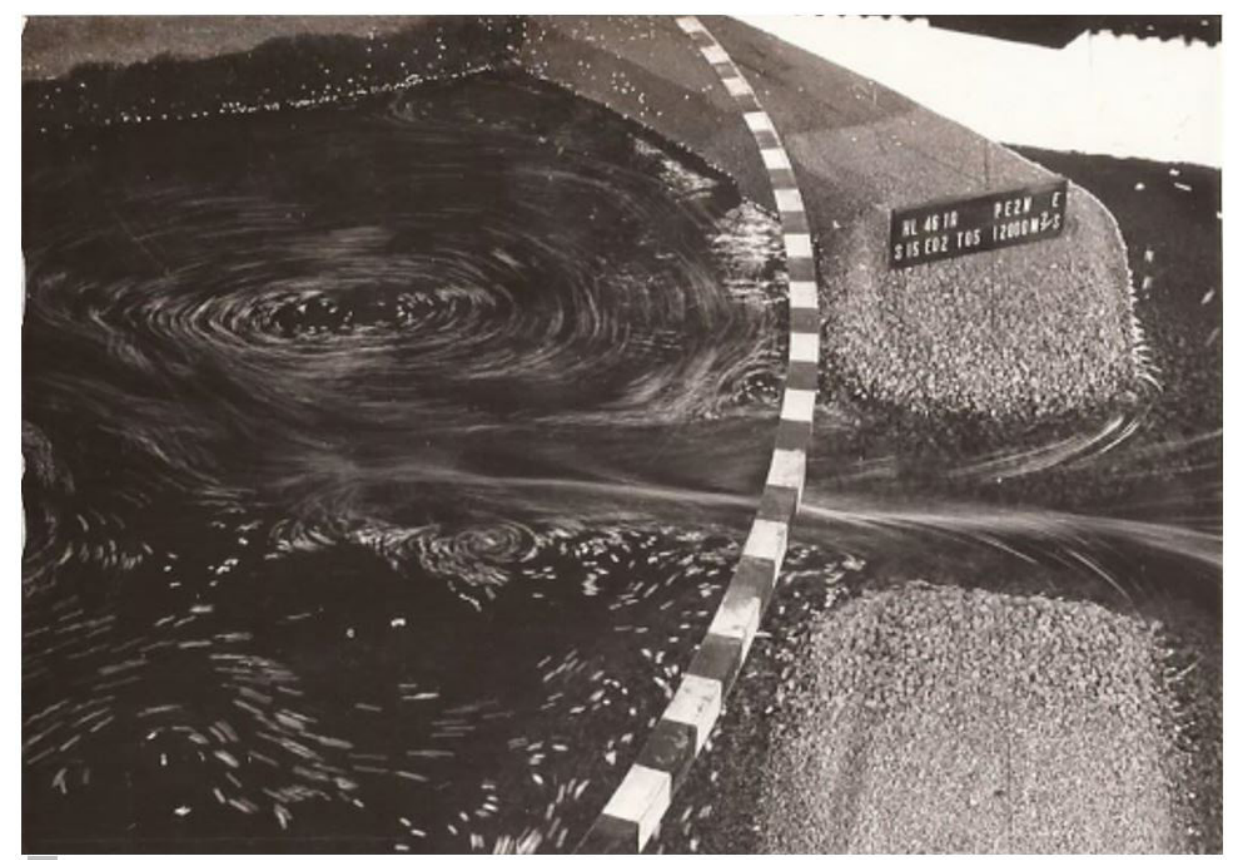

Figure 4. Hydraulic scale model study of the Paraná river closure to build the Itaipu Hydroelectric Plant. Source: CEHPAR (1976). 


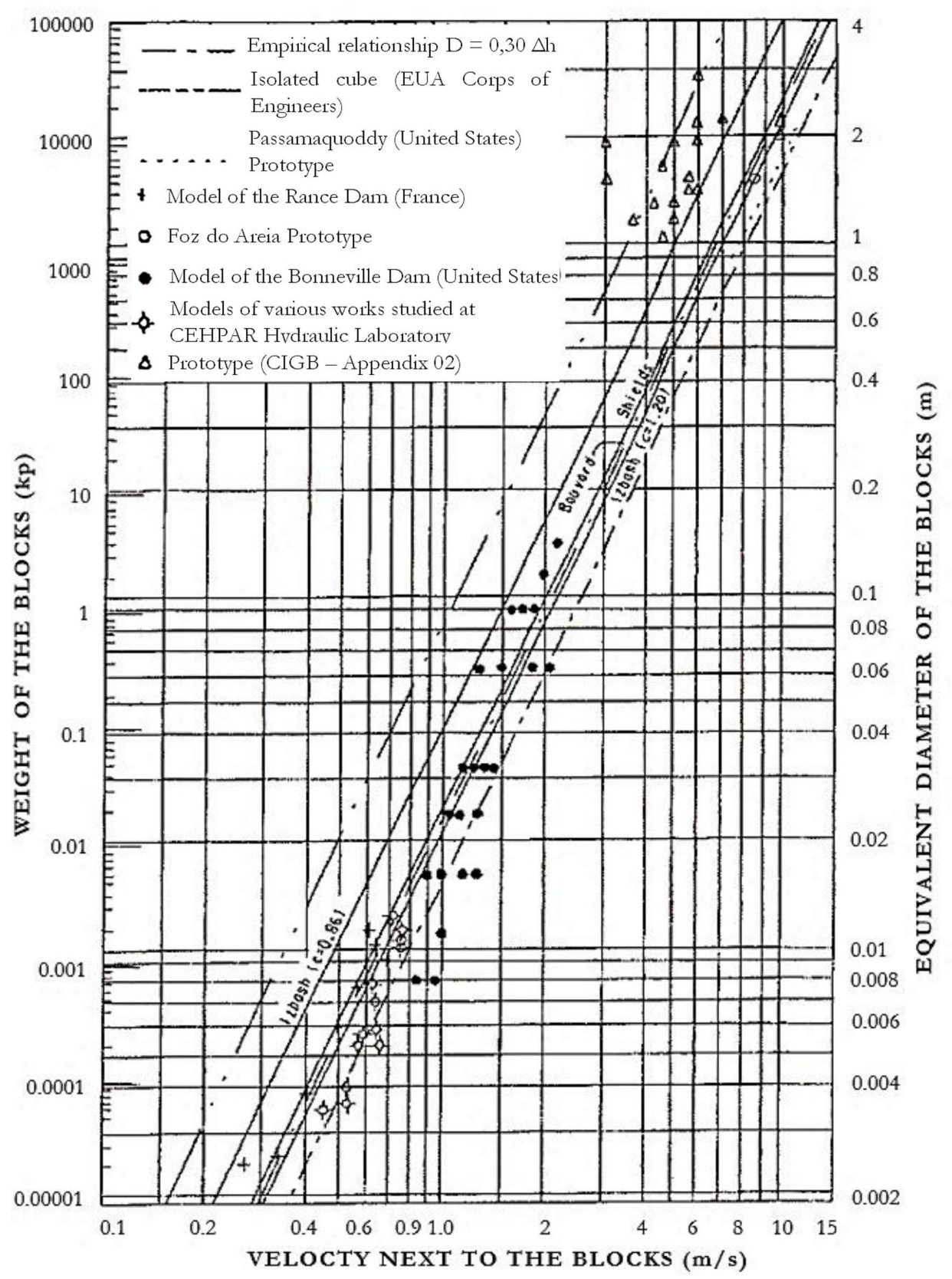

Figure 5. Relation of flow velocity versus weight and diameter of the blocks.

Source: Neidert and Tozzi (1986).

Laboratory, of the Foz do Areia prototype and of other prototypes (NEIDERT; TOZZI, 1986).

It can be seen that the materials used in the closures in prototypes covered in this figure, generally followed the criteria of conservative sizing. There is also an evident tendency of the straight lines that represent the methods of Isbash, Shields and Bouvard of keeping apart of the results of a hydraulic reduced scale model as the diameters diminish. This finding indicates, for a same diameter, that the material resists greater critical velocity in the scale model compared to the trend expected in the prototype indicated in this analysis by the methods of Isbash, Bouvard and Shields. Thus, in general, it is found that the results of the studies on a hydraulic scale model tend to undersize the material to be employed in closure in a prototype, the smaller the dimension of the material. In other words, to resist a same velocity, the results in a scale model indicate material with a smaller diameter than the established methods (PEREIRA, 2001). Recurrently, it is usual to attribute this deviation to effects of scale because of viscous action on the bed. Pereira (2001) remarks that the change of viscous action on the critical shear stress in the smaller diameters tends to place the smaller diameter in less stable conditions, and not the opposite. Thus, the fact that the smaller diameter material in the scale model resists greater velocities than the corresponding velocity in the prototype cannot be explained by the effect of viscous action on critical shear stress, since this effect is precisely the opposite. 
Pereira $(2001,2003)$ also found, based on his experimental studies, the importance of the configuration of the end dumping, and recommended the investigation of the field of velocities and the distribution of shear stress over the embankment, considering different configurations of end dumping, especially as to the embankment slope.

\section{Angle of repose of granular materials and the shape of the end dump}

Lane, in 1953, proposed the diagram shown in Figure 6 which relates the angle of repose $(\Phi)$ of materials to a relative density $\left(\mathrm{S}_{\mathrm{S}}\right)$ equal to 2.65 and diameter greater than $5 \mathrm{~mm}$.

The angle of repose of the material determines the cofferdam slope inclination as shown in Figure 7. Therefore, the diameter of the material imposes the shape of the end dump, which provokes a distortion in the scale model that uses small diameter material. In other words, end dumping in the model tends to present a gentler curvature than in the prototype.

Given that the curve flow can be considered irrotational, because it is a short transition, velocity $(\mathrm{V})$ in the end dumping region follows the classic relation of the free vortex, $\mathrm{V}=\mathrm{C} / \mathrm{r}$, where $\mathrm{C}$ is a constant and $\mathrm{r}$ the radius of curvature of the streamline. Therefore, velocity increases as the radius of the streamline diminishes, in other words, as the diameter of the material increases.

Thus it is demonstrated that the steeper the slope, the greater the velocity in that region compared to the velocity at the end dump with a lower slope.

\section{MATERIALS AND METHODS}

In the first stage of the study, the computational model, software FLOW 3D ${ }^{\circledR}$, was validated to reproduce the results obtained from physical model tests performed by Pereira (2001). A comparative analysis was done using the flow velocities at the end dump region.

The experimental investigation in a hydraulic scale model was performed in a channel with the following characteristics:

- Channel width: $\mathrm{B}=2.40 \mathrm{~m}$;

- Length of free flow: $14.47 \mathrm{~m}$;

- Depth upstream: $\mathrm{H}=0.60 \mathrm{~m}$;

- Discharge: $\mathrm{Q}=231 \mathrm{l} / \mathrm{s}$;

- Cofferdam material: $\mathrm{d}_{50}=7.42 \mathrm{~mm}$;

- Mean velocity of approach: $U=0.16 \mathrm{~m} / \mathrm{s}$.

Based on studies with material for closure,before its stability limit, Pereira (2001) obtained the geometry to make a fixed cofferdam (Figures 8, 9 and 10).

The velocities at the cofferdam boundary were recorded in the physical scale model, perpendicular to the inclination of the cofferdam slope at three alignments: $0^{\circ}, 45^{\circ}$ and $90^{\circ}$ and at three depths A, B and C, as shown in Figures 11 and 12. Depth A is the bottom of the channel, Depth B is $32.49 \mathrm{~cm}$ above the bottom of the channel, and depth $\mathrm{C}$ is $32.49 \mathrm{~cm}$ above $\mathrm{B}$ (Figure 12).

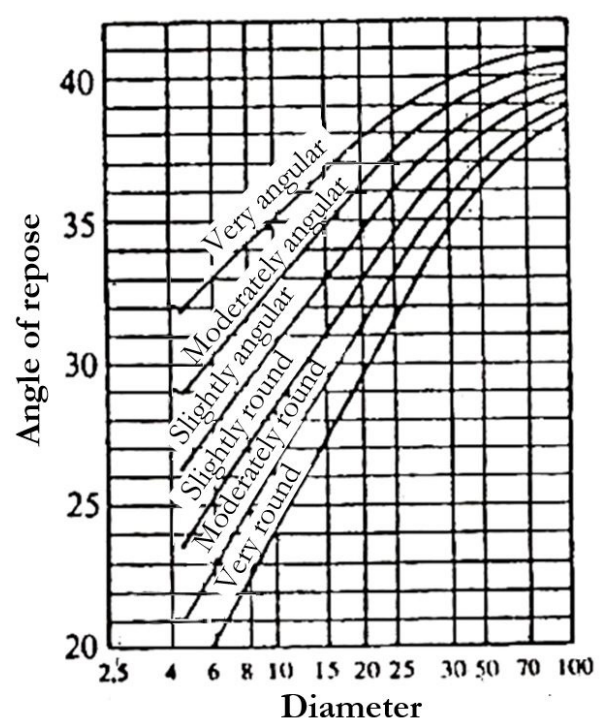

Figure 6. Angle of repose of non-cohesive material. Source: adapted from Lane (1953).

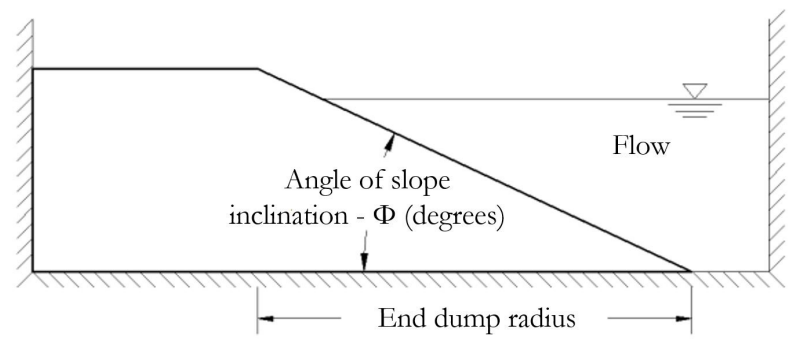

Figure 7. Angle of inclination of a cofferdam embankment.

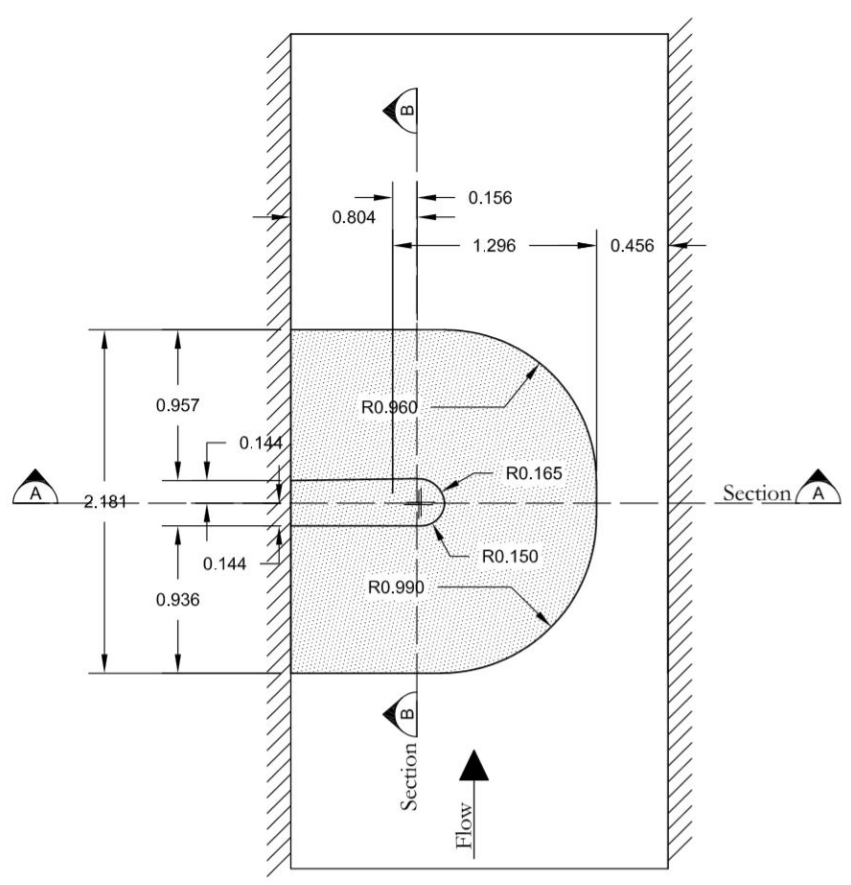

Figure 8. Plan and dimensions of cofferdam- experimental investigation.

Fonte: Pereira, 2001. 


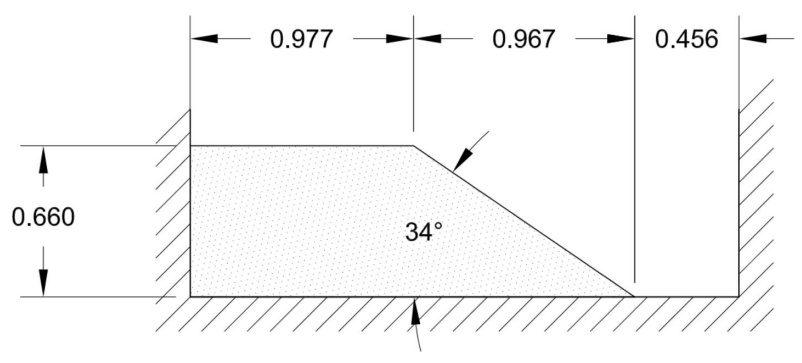

Figure 9. Section A. Source: Pereira, 2001.

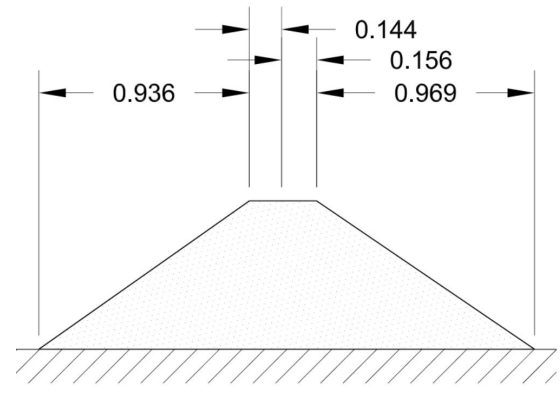

Figure 10. Section B. Source: Pereira, 2001.

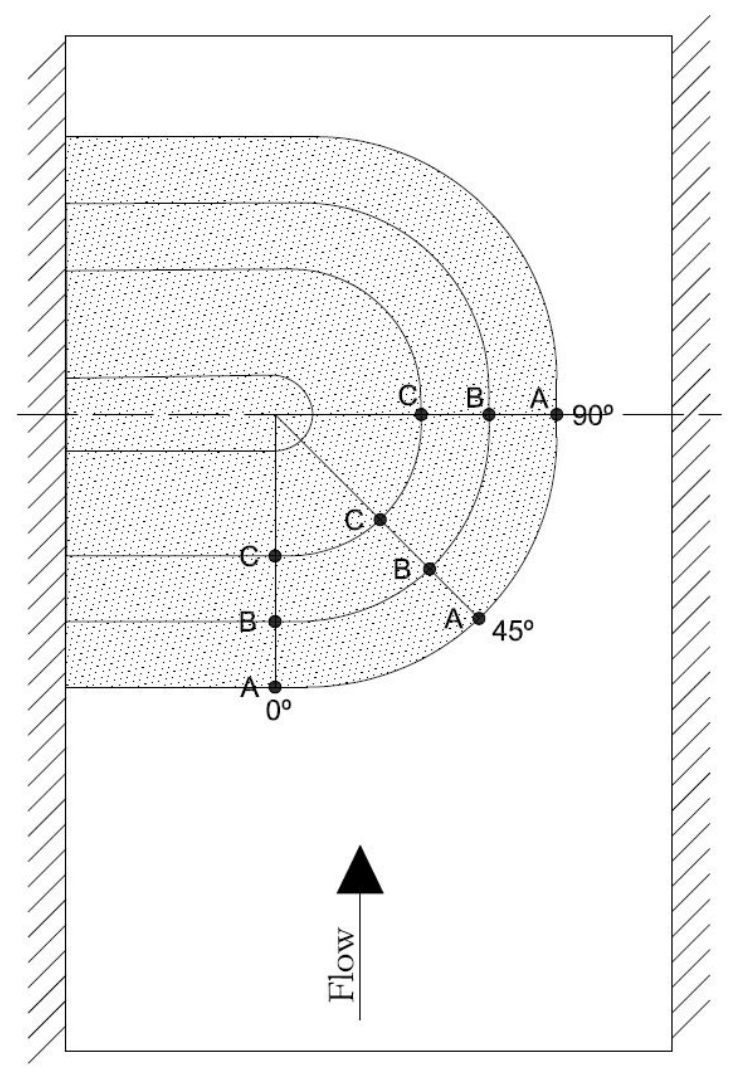

Figure 11. Cofferdam in the experimental investigation - Points where velocities were recorded around the end dump - Plan. Source: Pereira, 2001.

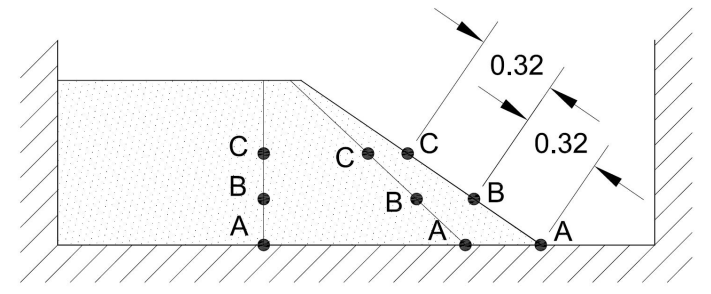

Figure 12. Cofferdam in the experimental investigation - Points where velocities were recorded around the end dump - Cross-Section. Source: Pereira, 2001.

The distances (h) of the points where the velocities are recorded are defined perpendicular to the cofferdam slope and are indicated in Figure 13. In the computational model, the velocity records were performed exactly at the same points as in the physical model.

FLOW $3 \mathrm{D}^{\circledR}$ is a three-dimensional program that uses the finite volumes approach to solve the Navier-Stokes equations with the Reynolds mean (Reynolds Averaged Navier-Stokes, i.e. RANS equations). The program solves these equations in the three dimensions using structured cartesian meshes (FLOW SCIENCE, 2011). In addition, FLOW $3 \mathrm{D}^{\circledR}$ utilizes the turbulence models to simulate turbulent flows. In this study, the RNG turbulence model was used (a two-equation model based on the theory of group normalization). This model is known for describing low intensity turbulent flows and regions with strong shear stress with greater precision (YAKHOT et al., 1992).

Based on the dimensions of the channel and of the cofferdam of the physical model, the geometry for computational simulation was developed in the AUTOCAD ${ }^{\circledR}$ program. The defined geometry sought to represent the channel and the cofferdam the same way as they were represented in the physical model (Figure 14). Roughness for the simulated cofferdam was defined as equal to the roughness of the cofferdam material in the scale model: $7.42 \mathrm{~mm}$. The roughness of the simulation channel, built of concrete in the hydraulics laboratory, was adopted for simulations in FLOW $3 \mathrm{D}^{\circledR}$ equal to $0.4 \mathrm{~mm}$.

The channel for the numerical study was made longer in length ( 3 meters upstream and 1.45 meters downstream) than the channel in the physical model. This was done so that the sections where the flow discharge and the water level were recorded (upstream and downstream) will not be the limiting sections of the model, so as to avoid interferences in accommodation of the flow, especially upstream.

Aiming to minimize and speed up the time of simulation of the studies in this work, it was defined that the simulations would be performed in series, beginning with a first simulation with a mesh composed by larger elements, until the final simulation with a mesh composed of smaller elements.

For the first simulation a single mesh was defined throughout the channel, with cubic elements of $0.05 \mathrm{~m}$ of edge, simulated during 360 seconds (real flow time). For the second simulation, besides the global discretization of $0.05 \mathrm{~m}$, the region closest to the cofferdam was refined with a $0.025 \mathrm{~m}$ mesh at a length that covers $2.5 \mathrm{~m}$ upstream from the 


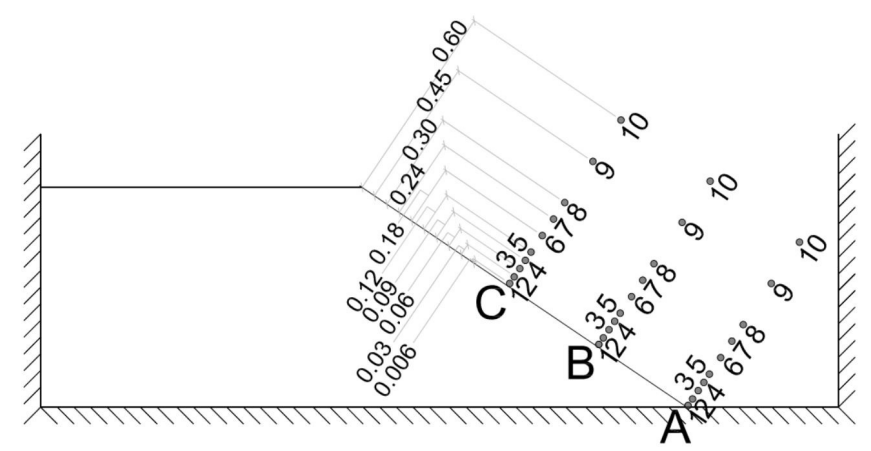

Figure 13. Distance from the points where velocity is recorded in relation to the cofferdam slope.

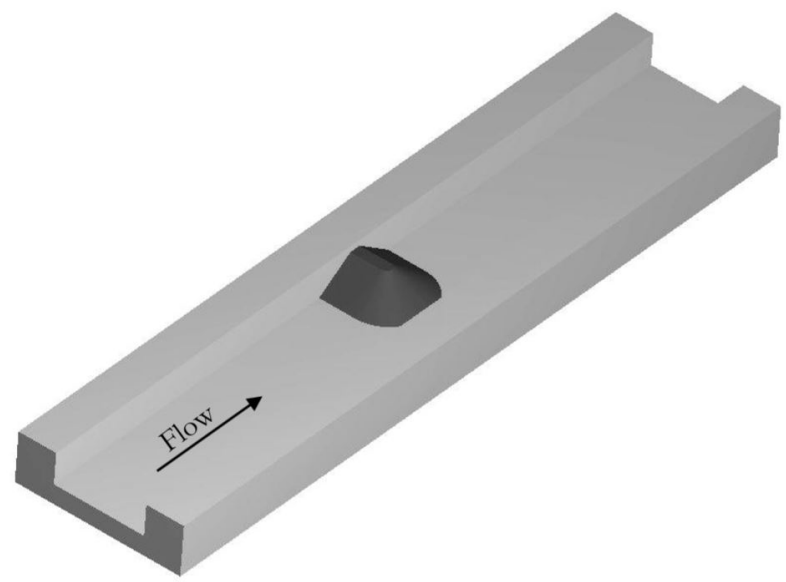

Figure 14. Channel and cofferdam in a computational model.

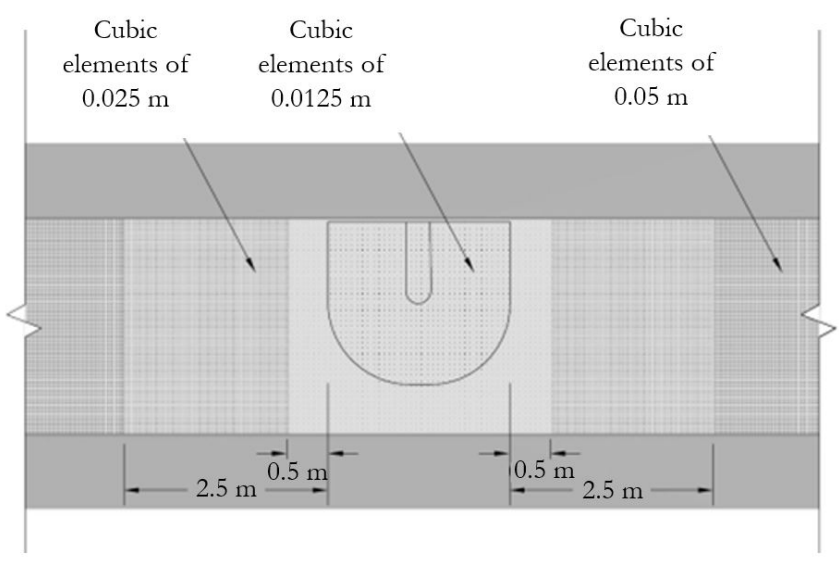

Figure 15. Mesh of finite volumes of final simulation in a computational model.

upstream extremity, and $2.5 \mathrm{~m}$ downstream from the downstream extremity of the cofferdam. The time defined for this simulation was 140 additional seconds from the first already finalized simulation. For the final simulation, based on the discretization that was already defined in the second simulation, a region even closer to the cofferdam was refined with a $0.0125 \mathrm{~m}$ mesh covering $0.5 \mathrm{~m}$ upstream and 0.5 downstream from the downstream extremity of the cofferdam. The latter configuration was simulated for 100 additional seconds from the second simulation that had already been finalized, totalizing 600 seconds of complete simulation. Figure 15 shows the overall aspect of the mesh for the final simulation.

The initial condition in the computational model was imposed equal to the water level downstream, aiming to be the closest possible to the final condition expected for the model. This was done so that the model is be able to rapidly reach the condition of permanent flow, and thus avoid numerical instabilities. The boundary conditions were defined: at the upstream extremity as an inflow to the channel and at the downstream extremity as a fixed water level. The downstream water level was defined using the following iterative process: a water level was adopted downstream, the first simulation was performed, and the upstream water level was verified. A new downstream water level was adopted until the upstream water level resulted equal to that of the scale model.

In order to analyze whether the simulation was adequate, and, therefore, if the computational model chosen, FLOW 3D ${ }^{\circledR}$, is validated for the subsequent studies, the velocity data obtained were tabulated and compared to the investigation in the physical model. Once the computational model was validated, the second stage of the study consisted in the simulation of configurations of end dump cofferdams, varying two main aspects of the cofferdam geometry: the crest width (and consequently the radius of the end dump) and the slope inclination.

In order to allow comparing and defining the effect of the variation of these two geometrical aspects of the end dump, the area of the gap caused by the original cofferdam defined by Pereira (2001) in a physical model, was kept fixed in the second stage studies. Besides maintaining the area of the gap and hence, the mean velocity in the gap, the geometry of the channel, the discharge and the levels of water upstream and downstream in the channel were maintained, guaranteeing the same conditions of the trials by Pereira (2001). Only the geometry of the cofferdam was altered in these simulations.

For the purpose of comparing the different cofferdam configurations simulated, records and analyses of the following parameters were performed: shear stress, velocity and streamlines around the cofferdam.

It is underscored that, with the change in the crest widths of the cofferdam, and consequently of the radius of the end dump, and also the alteration in the slope inclination, the recording points for the velocities accompanied these alterations for the purpose of maintaining the criteria of perpendicularity and distance from the recording points to the end dump.

In order to evaluate the effect of variation of the cofferdam crest width, it was planned to compare the original configuration, cofferdam defined by Pereira (2001), to three other configurations of crest width, according to geometries presented in Figure 16.

The variation of the slope inclination was studied considering an additional configuration as shown in Figure 17. 
Cofferdam $\mathrm{R}=0.1 \mathrm{~m}$

Original Cofferdam $(\mathrm{R}=0.15 \mathrm{~m})$

Cofferdam $\mathrm{R}=0.2 \mathrm{~m}$

Cofferdam $\mathrm{R}=0.4 \mathrm{~m}$
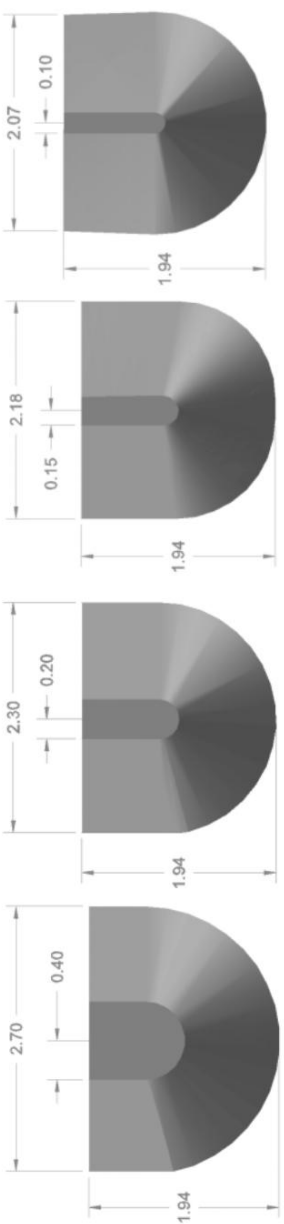

Figure 16. Study of the crest width variation. Source: Dalmora, 2015.

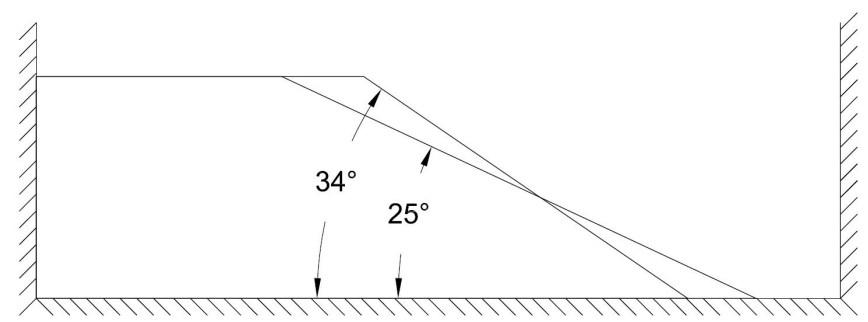

Figure 17. Original cofferdam ( $34^{\circ}$ slope) and cofferdam slope $25^{\circ}$ - cross section at the gap. Source: Dalmora, 2015.

\section{RESULTS AND DISCUSSIONS}

Figure 18 illustrates, for the three measurement sections, $\mathrm{A}, \mathrm{B}$ and $\mathrm{C}$, in the three alignments $0^{\circ}, 45^{\circ}$ and $90^{\circ}$, the comparison of the results of non-dimensionalized velocities $\mathrm{v}$ by the approach velocity $\mathrm{U}$, of the simulation in a computational model, with the results of the physical model presented by Pereira (2001).

The velocity profiles of the numerical simulations indicate a similarity between the experimental investigation performed on a physical model and the simulations performed in the computational model. For most of the points recording velocity

a) Relation $(\mathrm{v} / \mathrm{U})$ versus $(\mathrm{h} / \mathrm{H})$ relation - Section $\mathrm{A}$

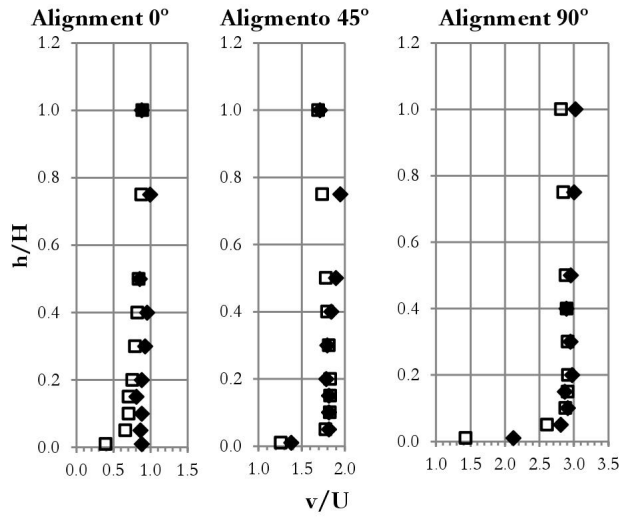

b) Relation $(\mathrm{v} / \mathrm{U})$ versus $(\mathrm{h} / \mathrm{H})$ - Section $\mathrm{B}$
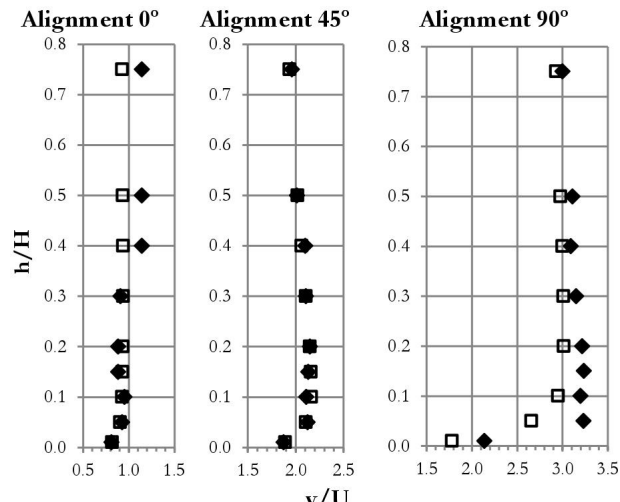

c) Relation $(\mathrm{v} / \mathrm{U})$ versus $(\mathrm{h} / \mathrm{H})-$ Section $\mathrm{C}$
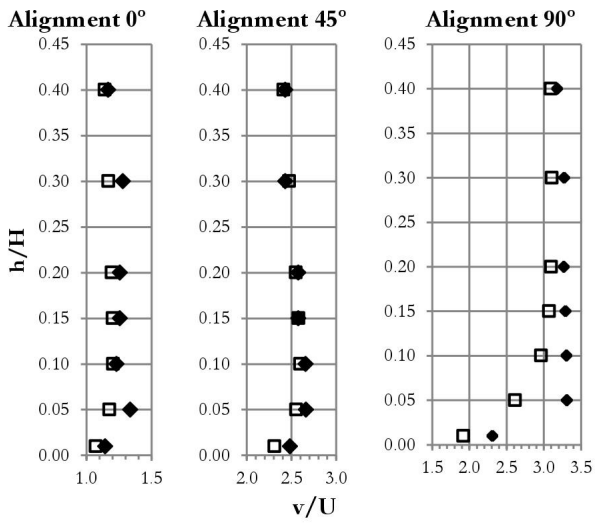

- Results of physical model Pereira (2001) $\checkmark$ Results of computational model

Figure 18. Relation (v/U) versus $(\mathrm{h} / \mathrm{H})$.

$(80 \%)$, the computational model presented results of velocities with a maximum difference of $10 \%$ in relation to the physical model. Generally, the computational model presented slightly lower results of velocities than the physical model.

The greatest difference between the velocity results recorded in the computational model and in the physical model was identified at the point closest to the cofferdam in Section A, in the Alignment $0^{\circ}$, in which the recording of velocity performed in the computational model was lower than the recording of velocity in the physical model. Other important isolated situations, that are, however, smaller, can also be identified. 
Generally, a few isolated inconsistencies are found regarding the expected tendency of the velocity profiles in the results of the physical model. This may be the result of the difficulty of measuring due to using the Pitot-Prandtl tube to record velocities in the physical model, such as the difficulty of eliminating air and time of stabilization. Pereira (2001) comments on the fact that

a) Relation $(\mathrm{v} / \mathrm{U})$ versus $(\mathrm{h} / \mathrm{H})-$ Section $\mathrm{A}$
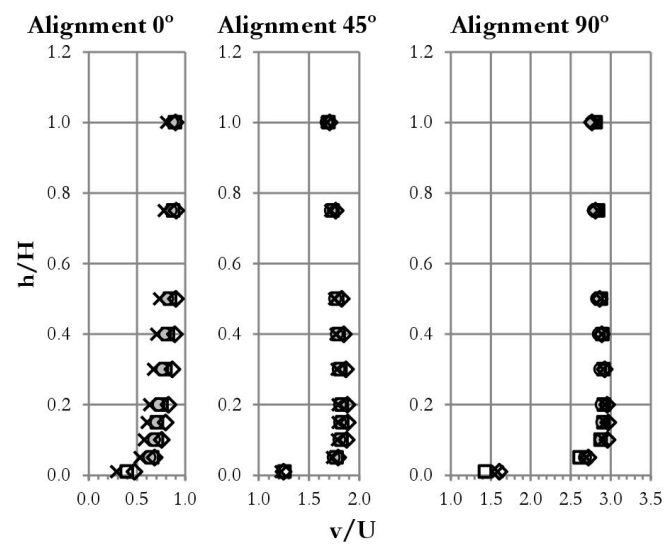

b) Relation $(\mathrm{v} / \mathrm{U})$ versus $(\mathrm{h} / \mathrm{H})-$ Section $\mathrm{B}$
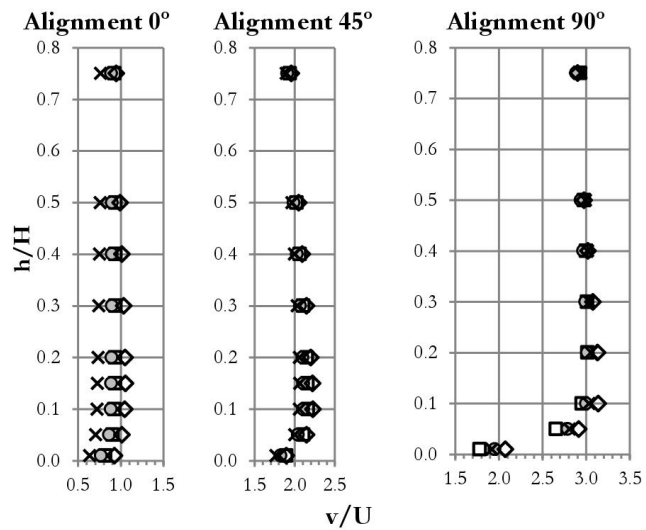

c) Relation $(\mathrm{v} / \mathrm{U})$ versus $(\mathrm{h} / \mathrm{H})-$ Section $\mathrm{C}$
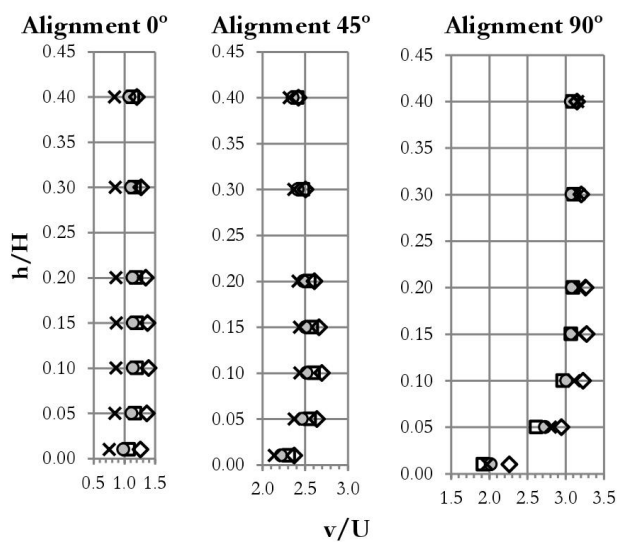

$\square$ Original cofferdam $(\mathrm{R}=0.15 \mathrm{~m})$ $\diamond$ Cofferdam $\mathrm{R}=0.1 \mathrm{~m}$ O Cofferdam $\mathrm{R}=0.2 \mathrm{~m}$ $\times$ Cofferdam $\mathrm{R}=0.4 \mathrm{~m}$

Figure 19. Variation of the cofferdam crest width - Relation $(\mathrm{v} / \mathrm{U}) \operatorname{versus}(\mathrm{h} / \mathrm{H})$. recording velocities using this equipment requires a lot of work and cites the great difficulty in recording velocities in Alignment $0^{\circ}$.

Knowing that the results of the physical model have distortions, it was understood that the computational model adopted can reproduce the flow studied by Pereira (2001) adequately.

Thus, the second stage of the numerical studies began, which, considering the same criteria and premises as the simulations of the first stage (mesh, boundary conditions, initial condition, etc) included the change of two parameters of the cofferdam geometry.

The cofferdam crest width was altered in three alternative additions to the simulation of the original cofferdam already performed (radius of end dump 0.15 meters) as already illustrated in Figure 16.

Figure 19 indicates, for the three measurement sections: A, B and C, in the three alignments studied, $0^{\circ}, 45^{\circ}$, and $90^{\circ}$, the comparison of the velocity profiles of the numerical simulations considering the variation of the end dump radius, It can be observed that the variation of velocities in the end dump region for the alternatives studied is more marked in Alignment $0^{\circ}$ than in Alignments $45^{\circ}$ and $90^{\circ}$.

For Alignment $0^{\circ}$, the reduction of the end dump radius (from $\mathrm{R}=0.15 \mathrm{~m}$ to $\mathrm{R}=0.1 \mathrm{~m}$ ) resulted in an increase on the order of up to $20 \%$ in flow velocity. It can also be observed that there is a reduction of the velocities in the end dump region of up to $8 \%$ for $\mathrm{R}=0.2 \mathrm{~m}$ compared to the original cofferdam

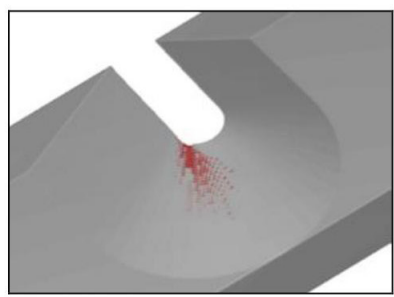

a)

Cofferdam

$\mathrm{R}=0.1 \mathrm{~m}$

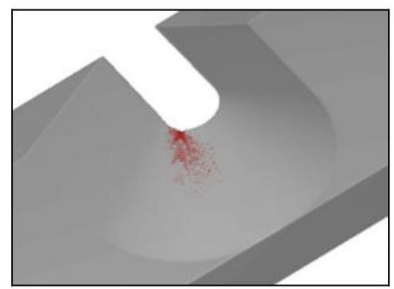

b)

Cofferdam $(\mathrm{R}=0.15 \mathrm{~m})$

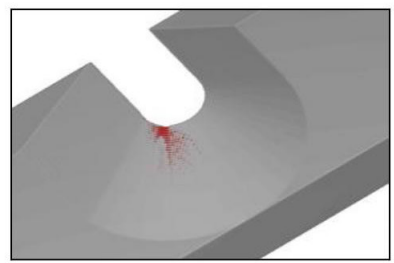

c)

Cofferdam $\mathrm{R}=0.2 \mathrm{~m}$

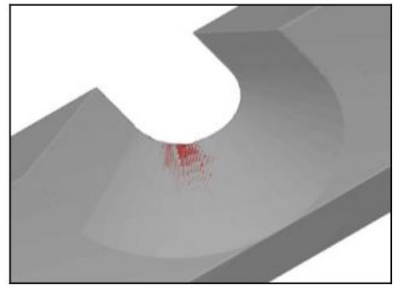

d)

Cofferdam

$\mathrm{R}=0.4 \mathrm{~m}$

Figure 20. Shear stress $\left(\mathrm{N} / \mathrm{m}^{2}\right)$. 
a)

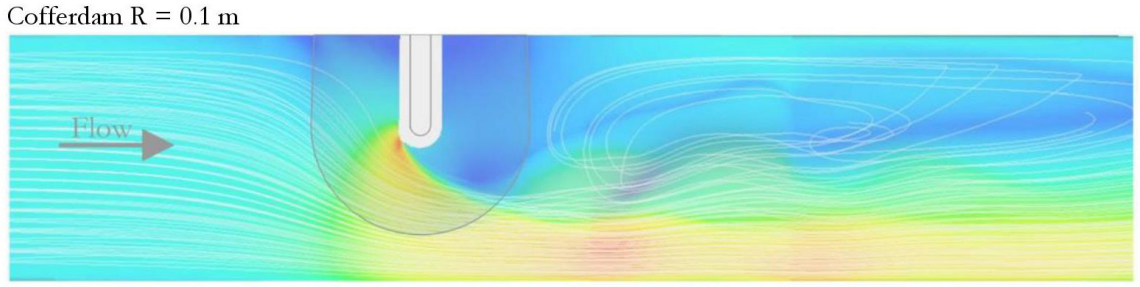

b) Original cofferdam $(R=0.15 \mathrm{~m})$

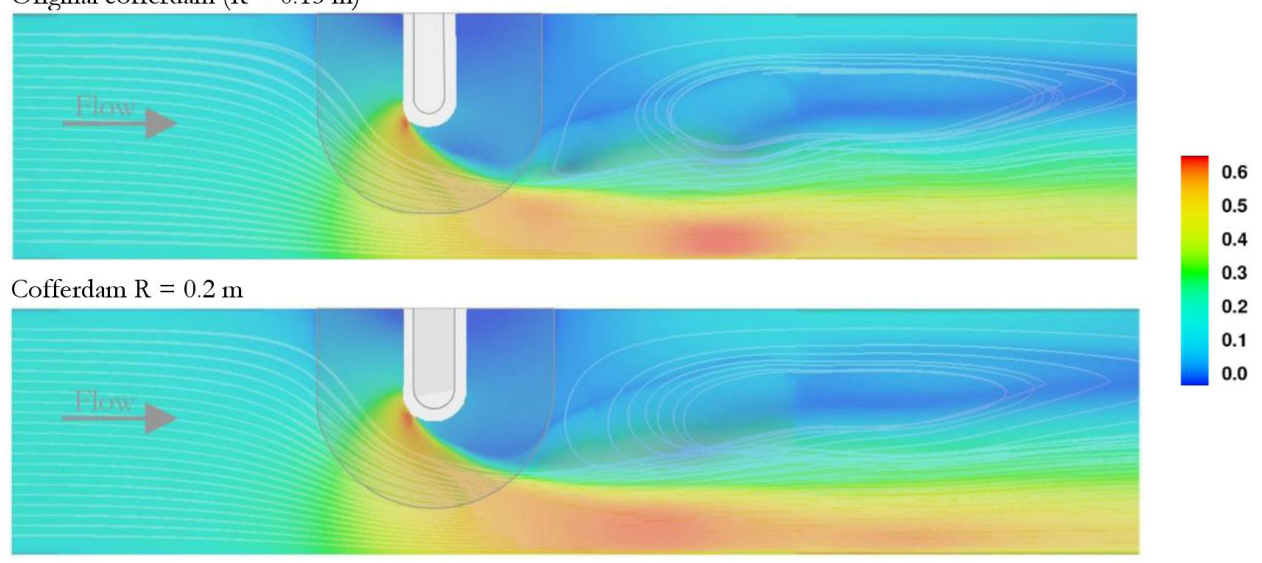

d) Cofferdam $R=0.4 \mathrm{~m}$

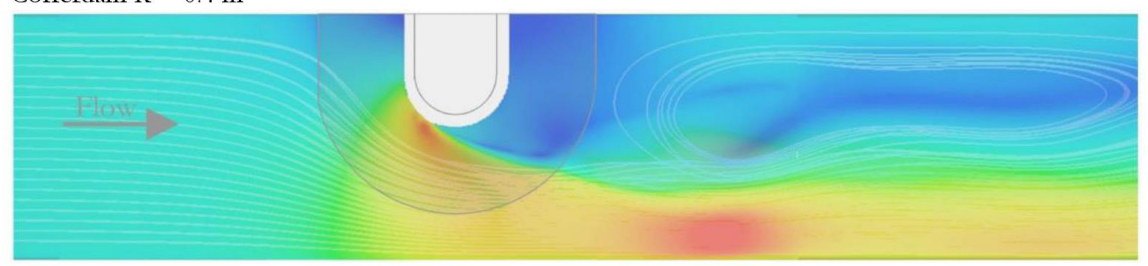

Figure 21. Streamlines and graphic velocity scale (m/s).

$(\mathrm{R}=0.15 \mathrm{~m})$ and on the order of $30 \%$ for the cofferdam with an end dump radius of $\mathrm{R}=0.4 \mathrm{~m}$ compared to the original cofferdam $(\mathrm{R}=0.15 \mathrm{~m})$.

In terms of shear stress the results of the computational model are shown in Figure 20. It can be seen that the area affected by the same range of values of shear stress represented by the color red diminishes with the increase of the end dump radius and consequent increase of the flow radius at the end dump.

Figure 21 shows a view from above of the flow streamlines and the graphic color scale represents the flow velocities on the surface. The scales of the figures were kept the same for the three cases studied. The objective of these figures is to emphasize the differences in the curvatures of the flow streamlines and in the distribution of velocities at the end dump among the cases studies.

Figure 22 compares the streamlines traced on the surface of the flow and close to the simulated cofferdams. A change of curvature is observed, with which the flow passes through the gap provoked by the obstruction of the cofferdam, according to the variation of the end dump radius. The larger the end dump radius, the greater the radius of the flow curvature in this region. There is clearly a greater radius of flow in the end dump region of "Cofferdam $\mathrm{R}=0.4 \mathrm{~m}$ " compared to the case in which $\mathrm{R}=0.1 \mathrm{~m}$.

The analysis of the flow streamlines for the four configurations studied (Figure 22), together with the graphic analysis of velocities

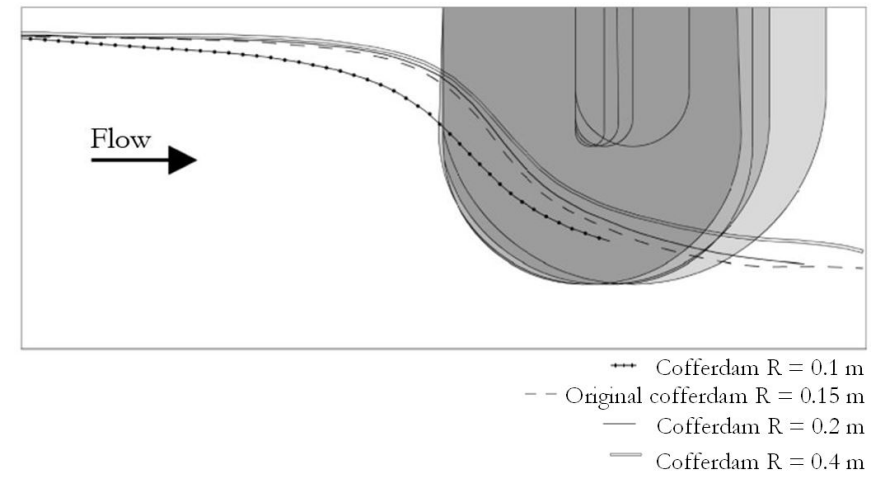

Figure 22. Comparison of streamlines of the simulated cofferdams.

in this region (Figure 21) indicates a greater concentration of velocities in a smaller area at the end dump, the smaller its radius. This effect is the consequence of the flow curvature in the end dump region that is smaller the smaller the radius of the end dump. The smaller the radius of the flow curvature in the end dump region, the more abrupt is the separation of flow downstream of the obstruction caused by the end dump.

Comparing the results of the simulation of these four configurations allows the main conclusion that the increased crest 
a) Relation $(\mathrm{v} / \mathrm{U})$ versus $(\mathrm{h} / \mathrm{H})-$ Section $\mathrm{A}$

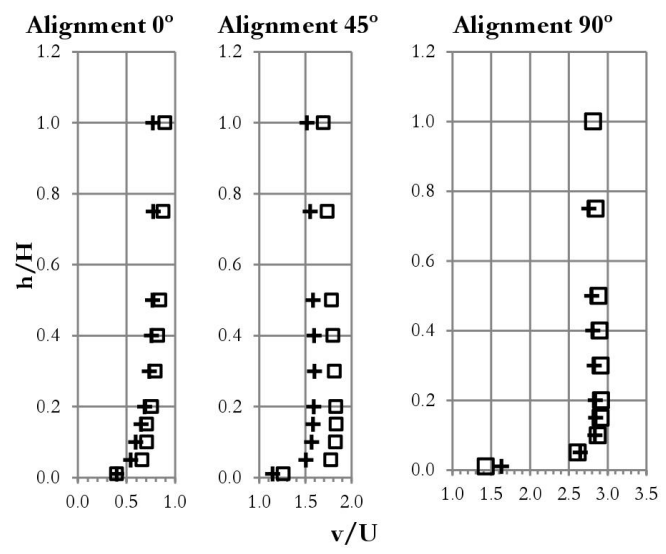

b) Relation $(\mathrm{v} / \mathrm{U})$ versus $(\mathrm{h} / \mathrm{H})-$ Section $\mathrm{B}$

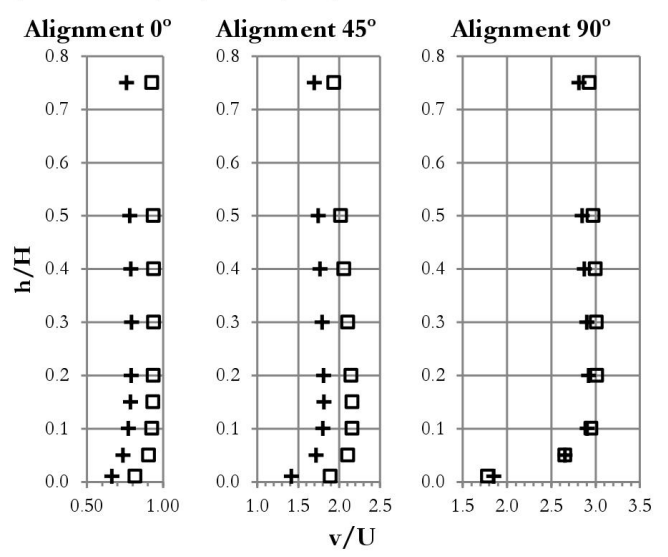

c) Relation $(\mathrm{v} / \mathrm{U})$ versus $(\mathrm{h} / \mathrm{H})-$ Section $\mathrm{C}$

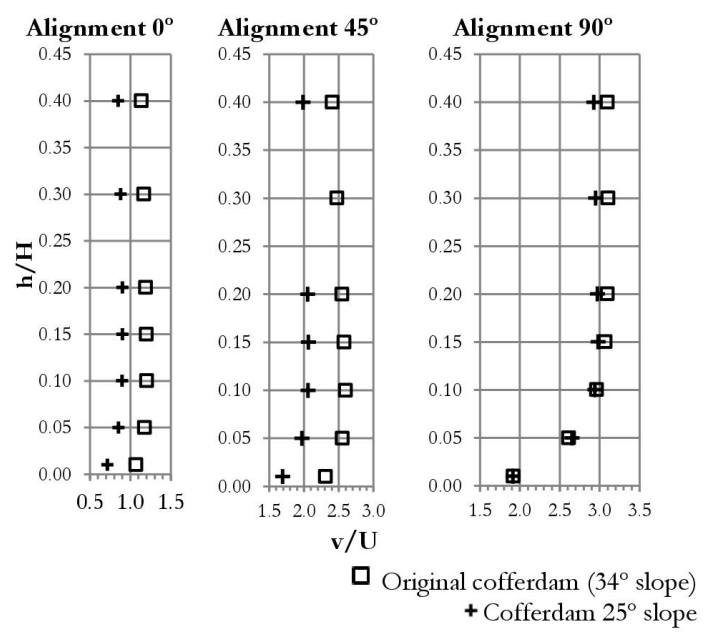

Figure 23. Variation of inclination of the cofferdam slope Relation (v/U) versus $(\mathrm{h} / \mathrm{H})$.

width of the cofferdam, and consequently, the increased radius of the end dump, results in a gentler, less abrupt contraction of flow. Consequently, there are lower velocities and shear stresses at the end dump.

Considering the change in the cofferdam slope inclination, Figure 23 shows the comparison of the results of computational simulation for the three measurement sections, in the three cofferdam alignments.

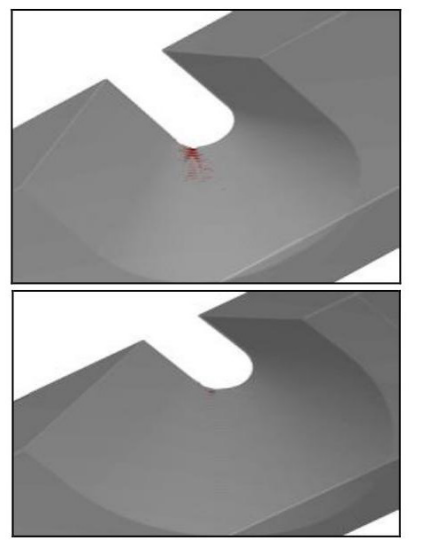

$\begin{aligned} & \text { a) Original } \\ & \text { cofferdam } \\ & \left(\text { slope } 34^{\circ}\right) \\ & \end{aligned}$
$\begin{aligned} & 4.50 \\ & \\ & \end{aligned}$
$\begin{aligned} & 4.00 \\ & 3.50 \\ & 3.00 \\ & 2.50 \\ & \text { b) Cofferdam } \\ & \text { slope } \\ & 25^{\circ}\end{aligned}$

Figure 24. Shear stress $\left(\mathrm{N} / \mathrm{m}^{2}\right)$.

For Alignment $0^{\circ}$ in the three sections of record, there was a reduction of the velocities recorded at the end dump of the cofferdam with a $25^{\circ}$ slope compared to the velocities recorded at the end dump of the cofferdam with a $34^{\circ}$ slope. Generally, this reduction was on the order of $20 \%$, and in section $\mathrm{C}$ reached velocity values on the order of $30 \%$ to $50 \%$ smaller than those recorded in the surroundings of the original cofferdam.

For Alignment $45^{\circ}$ there was also a reduction of the velocities in the three sections of record around the cofferdam with a $25^{\circ}$ slope compared to the velocities recorded at the end dump of the original cofferdam ( $34^{\circ}$ slope). In general this reduction was on the order of $20 \%$, reaching, in section C, velocity values $30 \%$ smaller than those recorded in the original cofferdam.

Compared to the behavior observed in Alignments $0^{\circ}$ and $45^{\circ}$, there was no major variation in the general behavior of velocities in Alignment $90^{\circ}$ of the two alternatives simulated (cofferdam slope $34^{\circ}$ and cofferdam slope $25^{\circ}$ ).

In terms of shear stress, the results were obtained graphically in the computational model according to Figure 24, with color scales defined equally for both cases. It is possible to identify that the area affected by the same range of values as the shear stress, represented by the color red, diminishes as the slope inclination diminishes (from $34^{\circ}$ to $25^{\circ}$ ), and is considerably smaller in Figure 24b) compared to Figure 24a).

Based on a view from above, Figure 25 indicates the flow streamlines and the graphic color scale represents the surface flow velocities. The objective of the format shown is to emphasize the difference of the flow curvature and the distribution of velocities at the end dump of the cofferdam among the cases studied. Analyzing these figures, it is clear that the velocities at the cofferdam end dump with a slope inclination of $25^{\circ}$ are smaller compared to the original cofferdam with a $34^{\circ}$ slope inclination.

Figure 26 compares the streamlines traced in the most superficial layer of the flow close by the cofferdams simulated considering the alteration in the slope inclination. It can be observed that the reduction of the cofferdam slope inclination causes a change in the flow curvature in the region of the gap, around the cofferdam. The smaller inclination of the slope resulted in a greater radius of the flow curvature. 
a) Original cofferdam (slope $34^{\circ}$ )

b)
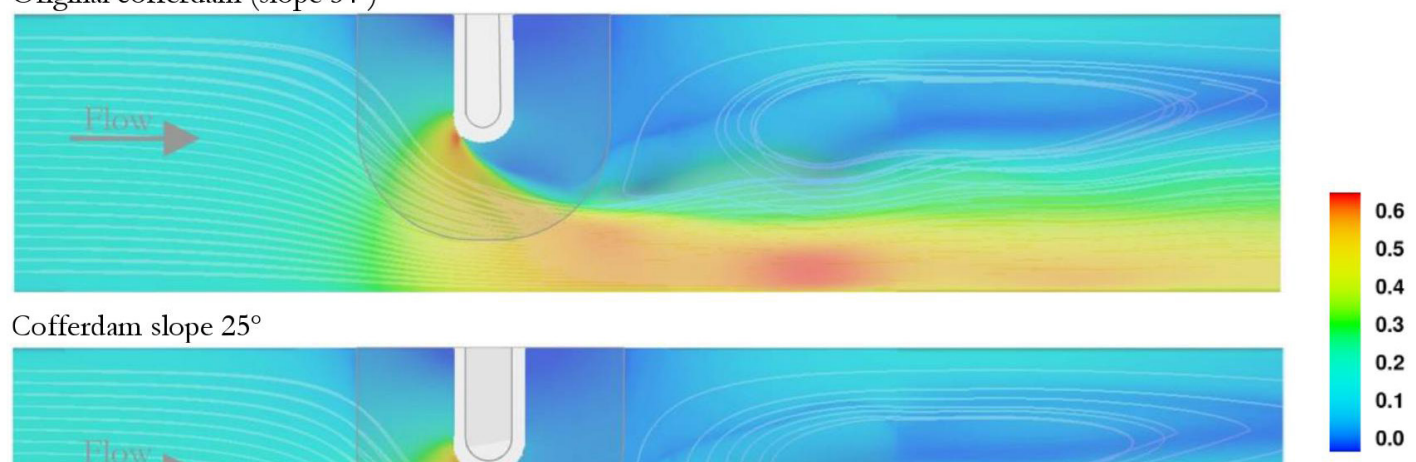

Figure 25. Streamlines and graphic velocity scale $(\mathrm{m} / \mathrm{s})$.

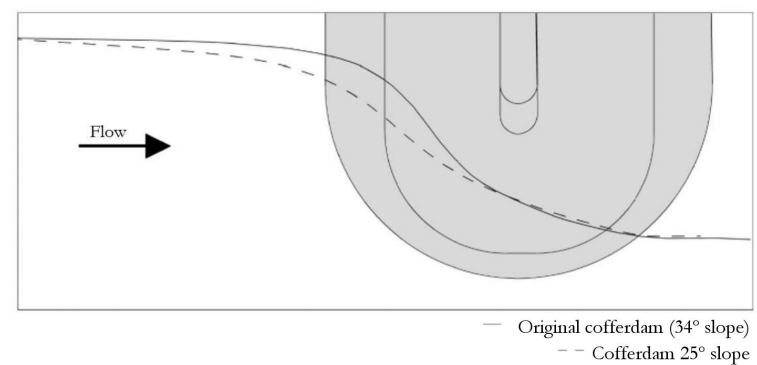

Figure 26. Comparison of the streamlines of the simulated cofferdams.

\section{CONCLUSIONS}

The present study sought to look at the behavior of flow around the end dump of a cofferdam built using the progressive lateral method, with the three dimensional computational model FLOW 3D ${ }^{\circledR}$.

The main objective of the study was to look at how the curvature of the streamlines imposed by the cofferdam geometry affects the flow characteristics in the end dump region. This investigation was performed based on the simulation of configurations of a cofferdam built by the end dumping method varying two main aspects of the geometry: the crest width (and consequently the end dump radius) and the slope inclination.

The parameters evaluated to verify and compare the effect of these variations of the end dump geometry on flow were: velocities, shear stress and streamlines.

In the first stage of the study, the computational model was validated utilizing the results of an experimental investigation on a physical model. The comparison of the velocity profiles obtained in a scale model (PEREIRA, 2001) and in the computational model allowed the conclusion that model FLOW $3 \mathrm{D}^{\circledR}$ manages to reproduce the flow at the end dump adequately.

A few isolated inconsistencies of the expected tendency of a velocities profile in the result of the physical model were identified and this may be the result of the difficulty to measure due to the use of the Pitot-Prandtl tube to record velocities in the physical model. Pereira (2001) comments on the fact that much work is needed to record velocities with this equipment and cites the great difficulty in recording velocities in Alignment $0^{\circ}$.

This conclusion should help the designers to solve difficulties and define river closure projects, since the computational model can be used as a tool to define alternative projects contributing to diminish uncertainties and solve problems.

As to the study of the geometry of the closure cofferdam, it is concluded that the increased end dump radius, and also the diminished inclination of the slope result in a larger radius of flow curvature at the end dump. This effect led to diminishing velocities and shear stresses in this region, since the interference (contraction) of the flow caused by the end dump is gentler and less abrupt.

Concerning the study of variation of the cofferdam slope inclination at the end dump, the results obtained in these studies provide an indication that may explain a scale effect inherent to the studies in a scale model. This is because the material used in the scale model studies is smaller (due to the model scale) than the material used for river closure in the prototype. Therefore, the angle of repose of the materials and, consequently, the inclination of the end dump slope will be different for the two cases (prototype and scale model). This fact contributes to the tendency of scale model results studies undersize the material to be used in closure in a prototype.

The present studies achieved the initially proposed objectives and contributed to greater knowledge regarding the flow characteristics around cofferdams constructed by the end dumping method.

The importance of the end dump configuration had already been underscored by Pereira (2001, 2003), who recommended investigating the field of velocities and distribution of shear stresses around the end dump considering different configuration, especially as to the embankment slope. 
Thus, this study led to an advance in these investigations, and the conclusions reiterate the importance of the configuration of the end dump, whose geometry affects the flow streamline curvature and consequently also the characteristics of flow in the end dump region. For this reason, future investigations and studies are recommended, especially seeking to approach a greater range of different configurations of the end dump geometry, as well as furthering studies related to the scale effects resulting from the different dimensions of the materials used in river closure studies in a scale model and in a prototype.

\section{REFERENCES}

BOUVARD, M. Barrages mobiles et prises l'éan en rivière. Paris: Eyrolles, 1960.

CEHPAR - CENTRO DE HIDRÁULICA E HIDROLOGIA PROFESSOR PARIGOT DE SOUZA. Projeto HL-46: estudos em modelo reduzido para o aproveitamento hidrelétrico do Rio Paraná, em Itaipu. Curitiba: CEHPAR, 1976. (Estudo do Fechamento do Rio Série de Provas Ensaios, n. 3 S-15).

CHANSON, H. The bydraulics of open channel flow: an introduction. Oxford: Elsevier, 2004.

CHAUDHRY, M. H. Open-channel flow. Columbia: Springer, 2008. http://dx.doi.org/10.1007/978-0-387-68648-6.

CIRIA - CONSTRUCTION INDUSTRY RESEARCH AND INFORMATION ASSOCIATION; CUR - CIVIELTECHNISCH CENTRUM UITVOERING RESEARCH EN REGELGEVING; CETMEF - CENTRE D'ÉTUDES MARITIMES ET FLUVIALES. The rock manual: the use of rock in hydraulic engineering. 2nd. ed. Londres: CIRIA, 2007. (CIRIA Special Publication, v. 683).

CURI, M. F. S. Fechamento do rio e estruturas normalmente utilizadas para desvio. 1986. 175 f. Dissertação (Mestrado em Engenharia) Escola Politécnica da Universidade de São Paulo, São Paulo, 1986.

DALMORA, C. T. Construção de ensecadeiras em água corrente estudo da estabilidade de material lançado em ponta de aterro. 2015. 135 f. Dissertação (Mestrado) - Universidade Federal do Paraná, Curitiba, 2015.

FLOW SCIENCE. FLOW 3D ${ }^{\circledR}$ user manual. version 10.0. Santa Fe, NM: Flow Science Inc., 2011.

GRAF, W. H. Hydraulics of sediment transport. Colorado: Water Resources Publications, 1984.

HENDERSON, F. M. Open channel flow. New York: MacMillan, 1966.

ICOLD - INTERNATIONAL COMMISSION ON LARGE DAMS. River control during dam construction. Paris: ICOLD, 1986. (ICOLD Bulletin, n. 48a)

ISBASH, S. V. Construction of dams by depositing rock in running water. In: Second Congress on Large Dams, 2., 1936, Washington, D. C. Proceedings... Washington: International Commission on Large Dams, 1938. p. 123-136.
ISBASH, S. V.; KHALDRE, K. Y. Hydraulics of river channel closure. London: Butterworths, 1970.

LANE, E. W. Progress report on studies on the design of stable channels by the Bureau of Reclamation. Reston: American Society of Civil Engineers, 1953. 31 p. (Proceedings ASCE, v. 79, n. 280).

NEIDERT, S. H.; TOZZI, M. J. Considerações sobre o dimensionamento do material de ensecadeiras construídas em ponta de aterro. In: Congresso Latinoamericano de Hidráulica, 3., 1986, São Paulo, SP. Anais... São Paulo: Associação Brasileira de Hidrologia e Recursos Hídricos, Comité Regional Latino Americano da AIPH, 1986. p. 416-425.

PEREIRA, M. A. C. Ensecadeiras de enrocamento construidas em água corrente pelo método de lançamento por ponta de aterro. 2001. 146 f. Dissertação (Mestrado) - Universidade Federal do Paraná, Curitiba, 2001.

PEREIRA, M. A. C. Considerações sobre o efeito de escala no dimensionamento do material ensecadeiras construídas em ponta de aterro. In: XXV Seminário Nacional de Grandes Barragens, 25. 2003, Salvador. Anais... Salvador: Comitê Brasileiro de Grandes Barragens, 2003. Disponível em: <http://www.cbdb.org.br/ documentos/site/91/9118.pdf>. Acesso em: 18 jun. 2017.

PINTO, N. L. S. Contribuição ao estudo das barragens de enrocamento construídas em água corrente. 1977. 144 f. Tese (Concurso de Professor Titular do Departamento de Hidráulica e Saneamento) - Universidade Federal do Paraná, Curitiba, 1977.

SHIELDS, A. Application of similarity principles and turbulence research to bed-load movement. Berlin: Prussian Research Institute for Hydraulic Engineering and Shipbuilding, 1936. (Original title: Anwendung der Aehnlichkeitsmechanik und der Turbulenzforschung auf die Geschuebebewegung).

TASK COMMITTEE ON PREPARATION OF SEDIMENTATION MANUAL. Sediment transportation mechanics: initiation of motion: progress report. Journal of the Hydraulics Division, n. 2, p. 291, 1966.

YAKHOT, V.; ORSZAG, S. A.; THANGAM, S.; GATSKI, T. B.; SPEZIALE, C. G. Development of turbulence models for shear flows by a double expansion technique. Physics of Fluids, v. 4, n. 7, p. 1510-1520, 1992. http://dx.doi.org/10.1063/1.858424.

\section{Authors contributions}

Claudia Trevisol Dalmora: literature review, contribution in the definition of the methodology, execution of the methodology (including the computational modeling), processing, analysis and discussion of the results, elaboration and revisions of the manuscript.

José Junji Ota: provided the general idea and important recommendations for the research, definition of the methodology, significant contribution to the discussion of results and final manuscript revisions and contributions. 